\title{
Preferences regarding the mode of Delivery IN OCCUPATIONAL GROUPS OF NURSES AND MIDWIVES
}

\author{
Paula Janczyk ${ }^{1, C, D, E, F}$, Sabina Gwoździańska, ${ }^{2, B, C, D}$, Patrycja Ostrogórska ${ }^{1, C, D, E, F}$, Magdalena Humaj-Grysztar, ${ }^{1, C, D, E, F}$, \\ Julia Nawrot ${ }^{1, C, D, E, F}$, Dorota Matuszyk $k^{1, A, C, D, E, F}$
}

${ }^{1}$ Section of Basic Obstetrics Training, Institute of Nursing and Midwifery, Faculty of Health Sciences, Jagiellonian University Medical College, Krakow, Poland

${ }^{2}$ Midwifery graduate, Institute of Nursing and Midwifery, Faculty of Health Sciences, Jagiellonian University Medical College, Krakow, Poland

Authors' contribution:

A. Study design/planning • B. Data collection/entry • C. Data analysis/statistics $\bullet$ D. Data interpretation $\bullet$ E. Preparation of manuscript $\bullet$ F. Literature analysis/search $\bullet$ G. Funds collection

\author{
Address for correspondence: \\ Patrycja Ostrogórska \\ Section of Basic Obstetrics Training \\ Institute of Nursing and Midwifery \\ Faculty of Health Sciences \\ Jagiellonian University Medical College \\ 38 Zamoyskiego St. \\ 31-523 Krakow, Poland \\ tel./fax: +48 126563727 \\ e-mail: patrycja.ostrogorska@gmail.com \\ SUBMITTED: 12.12 .2019 \\ ACCEPTED: 14.01 .2020 \\ DOl: https://doi.org/10.5114/ppiel.2019.92536
}

\begin{abstract}
Introduction: The rate of caesarean sections in Poland is constantly increasing. In Poland, the selection of the mode of delivery does not depend on the woman's will; however, the preferences of childbearing women are shaped by their knowledge and beliefs related to the labour. The preferences of nurses and midwives may be shaped by the specificity of the work performed by them.

Aim of the study: An analysis of the preferences related to the mode of delivery among occupational groups of nurses and midwives.

Material and methods: The studies were carried out among 202 nurses and midwives using the diagnostic poll method and the survey questionnaire technique. Our own survey questionnaire and the Self-report Labour Anxiety Questionnaire (KLP II) were used.

Results: The conducted studies demonstrated that $88.12 \%$ of midwives, compared to $75.25 \%$ nurses, prefer vaginal delivery. Midwives significantly more frequently $(p=0.005)$ than nurses indicated vaginal delivery as safer for the mother and for the child, and as allowing for faster recovery to normal physical fitness. For the nurses and midwives opting for the caesarean section, the most significant reasons were anxiety about perineal injuries and concern about the child's health. The midwives, more frequently than nurses, declared the selection of non-pharmacological methods of alleviating pain.

Conclusions: The practiced profession influences the decisions related to the preferred mode of delivery and to the interventions applied during labour. Labour anxiety is a feature that is more frequent among nurses.

Key words: midwife, nurse, caesarean section, vaginal delivery, preferences.
\end{abstract}

\section{INTRODUCTION}

Vaginal delivery is the most physiological mode of delivery. The development of medicine allows us to minimise perinatal complications and increase the quality of care. This has a positive impact on the health of the mother and of the child [1]. Despite this, the percentage of caesarean sections has been continuously increasing for over a dozen years. Estimated data indicate that $30-50 \%$ of pregnancies are finalised using this method. The World Health Organisation (WHO) recommends the percentage of labours finished in a surgical way not to exceed $10 \%$, because above this indicator a decrease of the percentage of perinatal mortality of the mother and child is not ob- served [2]. The highest percentages of surgical delivery are demonstrated in the Dominican Republic (59.3\%) and Brazil (56\%). The lowest percentage share of surgical deliveries is reported in Africa, even below 5\% [3]. In Poland in 2018 the percentage of caesarean sections increased to $43.7 \%$ [4]. There are many classifications of indications for carrying out a caesarean section. The basic division includes planned and non-planned indications [4, 5]. Moreover, in selected countries, excluding Poland, caesarean section on request of the female patient is respected, without existing medical indications. One of the dimensions of this indication may be also a lack of consent from the patient for an attempt to perform vaginal delivery after a past caesarean sec- 
tion (vaginal birth after caesarean - VBAC) [5]. According to the International Federation of Gynaecology and Obstetrics, (French: Fédération Internationale de Gynécologie et d'Obstétrique - FIGO), performing a caesarean section due to non-medical reasons is ethically not justified [6]. However, the analysis of women's approaches regarding the mode of delivery allows us to determining the reasons for their choice. Nurses and midwives form an occupational group, specific due to the received education and the type of performed work. Their opinion may differ from that of women who are not associated with the medical care sector.

\section{AIM OF THE STUDY}

The aim of the paper was to perform a comparative analysis of the preferences referring to the mode of delivery in occupational groups of nurses and midwives.

\section{MATERIAL AND METHODS}

The studies enrolled 202 female respondents who were not yet pregnant (101 nurses and 101 midwives). The studies were carried out in July 2018. The diagnostic poll method was applied with the use of the survey questionnaire technique. Two tools were used in the study: our own survey questionnaire and the standardised Labour Anxiety Questionnaire (KLP II) - a revised version, the structure and psychometric properties by Leszek Putyński and Mariusz Paciorek. Our own questionnaire included questions referring to socioeconomic data, demographic data, and statements assessing the preferences and approaches of the respondents regarding the mode of delivery and alleviating labour pain. The applied questions included single-choice, multiple-choice, and open, short-answer questions. The Labour Anxiety Questionnaire (KLP II) included nine statements. The provided answers allow the assessment of labour anxiety at four levels. Number values from 0 to 3 are assigned to the differentiated categories, in accordance with the key. Possible results range from 0 to 27 points. The higher the result, the higher the intensification of labour anxiety, in the following degrees: low, slightly increased, high, and very high. The Cronbach's alpha of the KLP II questionnaire is 0.69 [7]. The survey questionnaires were delivered online using a Google Form posted in groups comprising communities of nurses and midwives, after obtaining prior consent from group administrators. The participants were informed that the study was anonymous and that participation in it was voluntary.

The statistical elaboration of the results was performed using the BM SPSS v.16.0 software. In order to assess the occurrence of differences between qualitative variables, the chi-squared test was used. In case of comparisons of quantitative variables between two groups - due to the fact that the number of the analysed persons was known - Student's t-test was applied. The adopted level of significance of differences between the analysed groups was $\alpha \leq 0.05$.

The studied subjects were assigned to two groups, depending on the practiced profession: nurse or midwife. Women aged 21-27 years constituted $66.34 \%(n=134)$ of the studied subjects. The mean age of those surveyed was 26.93 years. The majority of the studied subjects had higher MA education $(59.90 \%, n=121)$, lived in a city inhabited by more than 100 thousand people $(50.50 \%, n=102)$, and had been working in their profession for up to five years maximum $(77.23 \%, n=156)$. Table 1 presents the characteristics of the analysed group.

Table 1. The characteristics of the analysed group

\begin{tabular}{|c|c|c|c|c|c|c|c|c|}
\hline \multirow[t]{2}{*}{ No. } & \multicolumn{2}{|c|}{ Feature of the analysed group } & \multicolumn{2}{|c|}{ Nurses } & \multicolumn{2}{|c|}{ Midwives } & \multicolumn{2}{|c|}{ In total } \\
\hline & & & $n$ & $\%$ & $n$ & $\%$ & $n$ & $\%$ \\
\hline \multirow[t]{3}{*}{1.} & \multirow[t]{3}{*}{ Age } & $21-27$ years & 59 & 58.42 & 75 & 74.26 & 134 & 66.34 \\
\hline & & 28-34 years & 31 & 30.69 & 21 & 20.79 & 52 & 25.74 \\
\hline & & $35-40$ years & 11 & 10.89 & 5 & 4.95 & 16 & 7.92 \\
\hline \multirow[t]{3}{*}{2.} & \multirow[t]{3}{*}{ Education } & higher - BA (Bachelor's degree) & 38 & 37.62 & 41 & 40.59 & 79 & 39.11 \\
\hline & & higher - MA (Master's degree) & 61 & 60.40 & 60 & 59.41 & 121 & 59.90 \\
\hline & & higher - PhD (Doctoral degree) & 2 & 1.98 & 0 & 0 & 2 & 0.99 \\
\hline \multirow[t]{3}{*}{3.} & \multirow{3}{*}{$\begin{array}{l}\text { Place of } \\
\text { residence }\end{array}$} & rural area & 24 & 23.76 & 23 & 22.77 & 47 & 23.27 \\
\hline & & city of less than 100 thousand inhabitants & 31 & 30.69 & 22 & 21.78 & 53 & 26.24 \\
\hline & & city of more than 100 thousand inhabitants & 46 & 45.54 & 56 & 55.45 & 102 & 50.50 \\
\hline \multirow[t]{4}{*}{4.} & \multirow{4}{*}{$\begin{array}{l}\text { Job seniority in } \\
\text { the profession }\end{array}$} & none & 3 & 2.97 & 5 & 4.95 & 8 & 3.96 \\
\hline & & up to 5 years & 74 & 73.27 & 82 & 81.19 & 156 & 77.23 \\
\hline & & $6-12$ years & 18 & 17.82 & 10 & 9.90 & 28 & 13.86 \\
\hline & & $13-18$ years & 6 & 5.94 & 4 & 3.96 & 10 & 4.95 \\
\hline
\end{tabular}




\section{RESULTS}

The midwives significantly more frequently ( $p=0.026)$ declared their willingness to undergo vaginal delivery than the nurses. The dependence between the preferences regarding the mode of delivery and the practiced profession is presented in Table 2 .

The most frequent reason for choosing vaginal delivery, which also significantly differed $(p=0.005)$ among the occupational groups, was the conviction of the safety of vaginal delivery for the child's health. Statistically significant differences were demonstrated between groups in the selection of motives: the desire to return to self-reliance faster $(p=0.003)$, and the desire to experience labour pain in order to enrich professional experience $(p<0.001)$ (Table 3$)$.

No statistically significant differences were noted between the occupational groups in any of the declared motives for caesarean section (Table 4). Both nurses $(55.00 \%)$ and midwives (71.43\%) demonstrated anxiety about perineal injuries $(p=0.446)$, and this was the most common reason indicated by the respondents. Nearly half of the interviewees (50\% of nurses and $42.86 \%$ of midwives) expressed concern about the health of their child as their chosen reason for planned caesarean. There were differences (not significant) in the reasons of poor experiences gained while working and the fear of operative birth (30\% and $25 \%$, respectively, for nurses and $57.14 \%$ in both for midwives). Similar percentages of nurses and midwives (almost a third in each) explained their choice by concern about their lack of influence on the course of the labour, the fear of the labour pain, or the deprivation of dignity and intimacy. None of the respondents considered acquaintances' opinion or lack of self-belief as a motive for caesarean section.

Statistically significant dependencies between the preferences related to the mode of delivery and education, the place of residence, and the workplace were not observed.

The majority of nurses (83.96\%) and midwives (89.36\%) declared their willingness to use any of

Table 2. The dependence between the preferences regarding the mode of delivery and the practiced profession

\begin{tabular}{|c|c|c|c|c|c|c|c|}
\hline & \multicolumn{7}{|c|}{ Would you like to give birth by vaginal delivery? } \\
\hline & \multicolumn{2}{|c|}{ Yes } & \multicolumn{2}{|c|}{ No } & \multicolumn{2}{|c|}{ I don't know } & \multirow{2}{*}{$\begin{array}{c}\text { Chi-squared test } \\
p\end{array}$} \\
\hline & $n$ & $\%$ & $n$ & $\%$ & $n$ & $\%$ & \\
\hline Nurses & 76 & 75.25 & 20 & 19.80 & 5 & 4.95 & 0.026 \\
\hline Midwives & 89 & 88.12 & 7 & 6.93 & 5 & 4.95 & \\
\hline In total & 165 & 81.68 & 27 & 13.37 & 10 & 4.95 & \\
\hline
\end{tabular}

Table 3. The frequency of the declared motives of vaginal delivery in occupational groups of nurses and midwives

\begin{tabular}{llcc}
\hline Motives in favour of vaginal delivery & \multicolumn{2}{c}{ Occupational group } & Chi-squared test \\
\cline { 2 - 4 } & Nurses & Midwives & $p$ \\
\hline I know that it is the mode of delivery that is the best and the safest for my child & $61.73 \%$ & $80.85 \%$ & 0.005 \\
\hline $\begin{array}{l}\text { I want to get fit again after labour and be independent in the care provided to my } \\
\text { child as soon as possible }\end{array}$ & $46.91 \%$ & $69.15 \%$ & 0.003 \\
\hline I am a midwife/nurse and I know that I should try to give birth by vaginal delivery & $32.10 \%$ & $27.66 \%$ & 0.524 \\
\hline $\begin{array}{l}\text { I want to prove to myself that I am a strong woman, reinforce my self-esteem. } \\
\text { Vaginal delivery will make me feel more feminine }\end{array}$ & $7.41 \%$ & $13.83 \%$ & 0.171 \\
\hline $\begin{array}{l}\text { I want to prove to others that I am a strong woman, impress my colleagues, partner, } \\
\text { friends }\end{array}$ & & & \\
\hline $\begin{array}{l}\text { The possibility to undergo family labour. I want the father of my child to be with me } \\
\text { during labour, due to the positive influence on the relationship between partners }\end{array}$ & $32.10 \%$ & $3.06 \%$ & 0.347 \\
\hline $\begin{array}{l}\text { I want to personally experience what labour pain is - this will positively influence } \\
\text { my collaboration with patients and the understanding of their needs }\end{array}$ & $11.11 \%$ & $52.13 \%$ & $<0.780$ \\
\hline $\begin{array}{l}\text { Vaginal delivery is less invasive than a caesarean section; I believe that a caesarean } \\
\text { section is frequently a needless surgery entailing numerous consequences }\end{array}$ & $58.02 \%$ & $65.96 \%$ & 0.001 \\
\hline $\begin{array}{l}\text { I want to give birth by vaginal delivery because that is the way my acquaintances, } \\
\text { friends, my loved ones from the family gave birth and they have got very positive } \\
\text { labour experiences }\end{array}$ & $1.23 \%$ & $1.06 \%$ & 0.922 \\
\hline \begin{tabular}{l} 
I am obese and I believe that after vaginal delivery I will return to fitness faster \\
\hline
\end{tabular} & & & \\
\hline
\end{tabular}


Table 4. The frequency of the declared motives of a caesarean section in occupational groups of nurses and midwives

\begin{tabular}{|c|c|c|c|}
\hline \multirow[t]{2}{*}{ Motives in favour of a caesarean section } & \multicolumn{2}{|c|}{ Occupational group } & \multirow{2}{*}{$\begin{array}{c}\text { Chi-squared test } \\
p\end{array}$} \\
\hline & Nurses & Midwives & \\
\hline $\begin{array}{l}\text { I am afraid of labour pain (the contractions, pains of the sacrum bone, bearing- } \\
\text { down pains) }\end{array}$ & $35.00 \%$ & $28.57 \%$ & 0.757 \\
\hline I am afraid of perineal incision/tear & $55.00 \%$ & $71.43 \%$ & 0.446 \\
\hline $\begin{array}{l}\text { I am concerned about the health of my child - I believe that the condition } \\
\text { of neonates born through a caesarean section is better }\end{array}$ & $50.00 \%$ & $42.86 \%$ & 0.752 \\
\hline I believe that vaginal delivery deprives a woman of dignity and intimacy & $30.00 \%$ & $28.57 \%$ & 0.941 \\
\hline $\begin{array}{l}\text { I have got bad experiences from my professional work (e.g. improper conduction } \\
\text { of labour, unnecessary medicalisation) }\end{array}$ & $30.00 \%$ & $57.14 \%$ & 0.198 \\
\hline $\begin{array}{l}\text { I believe that women after vaginal delivery have got lower sexual satisfaction than } \\
\text { those after a caesarean section and I am concerned about my sexual intercourse } \\
\text { after labour }\end{array}$ & $55.00 \%$ & $28.57 \%$ & 0.231 \\
\hline I am afraid of labour finishing with the assistance of a vacuum extractor/forceps & $25.00 \%$ & $57.14 \%$ & 0.118 \\
\hline $\begin{array}{l}\text { I am afraid that despite attempts to undergo vaginal delivery, the labour will end } \\
\text { with a caesarean section }\end{array}$ & $25.00 \%$ & $0 \%$ & 0.137 \\
\hline $\begin{array}{l}\text { I am afraid of sudden, stressful situations. I prefer a prior planned date of delivery } \\
\text { through a caesarean section - "caesarean section on request" }\end{array}$ & $30.00 \%$ & $42.86 \%$ & 0.543 \\
\hline
\end{tabular}

Table 5. The preferred methods of alleviating labour pain in the occupational groups of nurses and midwives

\begin{tabular}{lccc}
\hline The preferred methods of alleviating pain & \multicolumn{2}{c}{ Occupational group } & Chi-squared test \\
\cline { 2 - 4 } & Nurses & Midwives & $p$ \\
\hline Conduction anaesthesia (spinal block, epidural analgesia) & $33.66 \%$ & $39.60 \%$ & 0.376 \\
\hline Pudendal anaesthesia & $9.90 \%$ & $4.95 \%$ & 0.183 \\
\hline Analgesics and antispasmodics & $33.66 \%$ & $29.70 \%$ & 0.551 \\
\hline Transcutaneous electrical nerve stimulation - TENS & $7.92 \%$ & $39.60 \%$ & $<0.001$ \\
\hline Massage and counter-pressure & $27.72 \%$ & $55.45 \%$ & $<0.001$ \\
\hline Inhalation analgesia - 50\% nitrous oxide & $16.83 \%$ & $36.63 \%$ & 0.001 \\
\hline Water immersion & $19.80 \%$ & $73.27 \%$ & $<0.001$ \\
\hline Vertical positions & $21.78 \%$ & $76.24 \%$ & $<0.001$ \\
\hline Acupressure & $2.97 \%$ & $8.91 \%$ & 0.073 \\
\hline Acupuncture & $1.98 \%$ & $4.95 \%$ & 0.254 \\
\hline
\end{tabular}

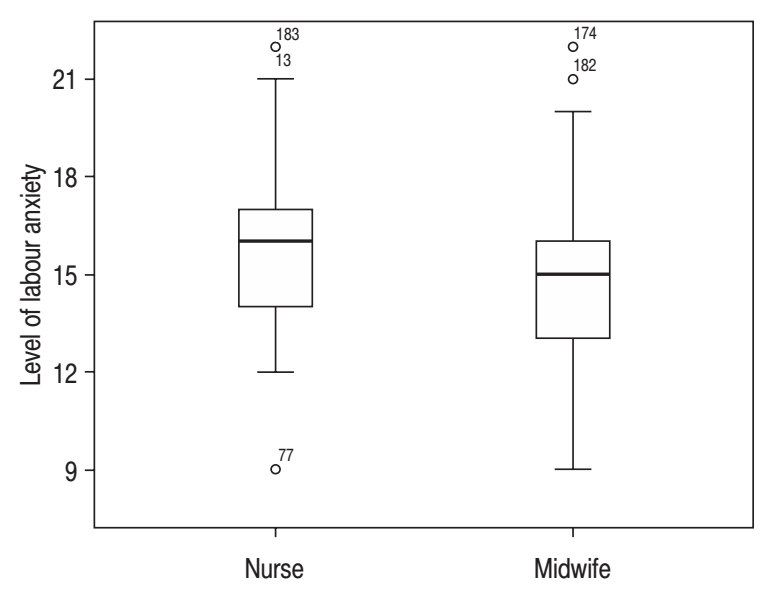

Figure 1. The distribution of the level of labour anxiety among nurses and midwives $(p=0.001)$ the methods of alleviating labour pain. More than one third of the studied subjects selected conduction anaesthesia (i.e. epidural) $(33.66 \%$ for nurses and $39.6 \%$ for midwives). One third of respondents in both groups would be willing to use analgesics and antispasmodics drugs. When offered non-pharmacological methods of relieving pain the midwives, significantly more often than the nurses $(p \leq 0.001)$, declared their willingness to use methods such as TENS, massage, water immersion, and vertical positioning (Table 5).

The conducted studies included performing an assessment of the level of anxiety among midwives and nurses using the Labour Anxiety Questionnaire. A higher level of labour anxiety was observed among the nurses than among the midwives (statistically significant result $p=0.001$ ) (Figure 1). 


\section{DISCUSSION}

The global assessment of gynaecologists' opinions, carried out in 2016, indicates the preferred percentage of caesarean sections at the level of $20 \%$ [8]. In the present study the willingness to undergo vaginal delivery was demonstrated by $88.12 \%$ of midwives and $75.25 \%$ of nurses. The result above was undeniably influenced by the specificity of the profession, practice, competence, and knowledge regarding the dominating advantages associated with vaginal delivery. However, comparing the two occupational groups, the difference between the obtained result is statistically significant, and vaginal delivery is more frequently desired by midwives than by nurses.

While analysing the views of midwives regarding the optimum mode of delivery, Baran and SkrętMagierto also indicate that $89 \%$ of studied subjects would choose vaginal delivery [9]. Medical professionals from Germany indicated that vaginal delivery was preferred by $90.4 \%$ of them [10].

However, the studies carried out by Guzikowski et al. [11] and by Podwińska et al. [12] among female Poles not professionally bonded with the medical sector demonstrate that only $62.1 \%$ and $66.5 \%$ of studied subjects would select vaginal delivery if they had the possibility to choose. The fact that the vast majority of studied nurses and midwives are in favour of undergoing vaginal delivery is duly correct; however, the fact that raises concern is that the quite large percentage of studied women opting for caesarean section on request. In the studies carried out by Michałowska et al. Polish female respondents believe that the selection of the mode of delivery should be a standard and it should be entitled to every woman [5]. Women's preferences regarding the mode of delivery are not always respected in Poland. In the present study $19.8 \%$ of analysed nurses declared a willingness to undergo a caesarean section, compared to $6.93 \%$ of midwives. Undergoing a planned caesarean section without medical indications constitutes the fourth (among midwives) and the fifth (among nurses) most frequently selected motive for a caesarean section. The lowest percentage of those willing to undergo a caesarean section on request among women was obtained in the studies by Konopka et al., at $18.5 \%$ [13]. The results of three Polish studies conducted by Podwińska, Wardak, and Bąk demonstrate that, respectively, $40.8 \%$, $58 \%$, and $65 \%$ of randomly selected women expect a caesarean section without indications $[12,14,15]$. These results are close to those from Chinese and Turkish birth professionals' modes of delivery outcomes, in which $49 \%$ and $54.78 \%$ underwent caesarean on request $[16,17]$.

One of the questions included in the survey, which enabled a reliable analysis of the tendencies of the medical staff regarding the preference for a caesarean section on request, was the possibility to select the motive for a surgical delivery. In our own studies, one of the three most frequent stimulants influencing the selection of caesarean section rather than vaginal delivery was concern about the quality of sexual intercourse after labour. As many as a half of nurses and one third of midwives believed that vaginal delivery causes the lowering of sexual satisfaction. Half of professionals in Turkey, one third in Germany, and one fifth in China share the same fear $[10,17,18]$. In the work by Guzikowski et al. it was demonstrated that this concern refers to only $3.2 \%$ of women [11]. The grounds for the occurring discrepancy may be the number of children born by the analysed women, because the present paper analyses only the preferences of nulligravidae.

The studies from Sweden and Poland do not prove that factors such as transient anxiety about pain or about labour, the retrospective assessment of pain sensations, or the number of experienced labours have an influence on the selection of the mode of delivery [19-21]. In turn, they indicate a significant influence of anxiety as a feature, i.e. of perpetuated anxiety reactions referring to all the situations associated with labour, on the selection of the caesarean section [20]. Caesarean section was considered a less painful experience than natural birth by $52.7 \%$ of Turkish respondents [17]. In the present study the experience of labour pain and the anxiety about it were not the main reasons for the selection of the caesarean section among both analysed groups. However, the occupational group of nurses demonstrated a significantly higher level of anxiety than the group of midwives.

The most frequently indicated motive was anxiety about perineal injuries, which was at a similar level by nurses and midwives (63.2\%), which constitutes a two-fold higher percentage than that indicated by Wardak et al. (32.4\%) [14] and almost six times higher than that indicated by Ouyang and Zhang [16]. However, our own results are reflected in those obtained by Bąk et al., where, just as in our own studies, the anxiety about episiotomy was higher among the studied subjects than the anxiety about labour pain [15]. It is also indicated as up to $59 \%$ in results from an Asian systematic review by Long et al. and a survey by Arikan et al., in which $63.6 \%$ of professionals were afraid of anorectal trauma, which was the main indication for caesarean on request $[17,18]$.

It is also worth underlining that more than a half of the surveyed midwives opting for the caesarean section indicated negative experiences from professional work as the motive for selecting this mode of delivery. This was the second most frequent reason indicated by midwives, after anxiety about perineal injuries, and at the same level as anxiety about 
a vacuum extractor/forceps-assisted delivery. Fear of injury to the foetus, unpredicted risk, and disbelief of vaginal delivery were reasons for nearly $80 \%$ professionals for selecting caesarean section in China [16].

Regardless of the preferences related to the mode of delivery, it is assessed that $50 \%$ of women experiencing labour pain significantly require minimising or reducing pain experiences [22]. In our own studies, the majority $(86.65 \%)$ of nurses and midwives demonstrated a willingness to use methods of alleviating pain during their labour. A statistically significant disproportion referring to the selection of the methods of alleviating labour pain was noticed among the studied groups. The midwives more frequently preferred non-pharmacological methods of alleviating pain, and the nurses preferred pharmacological ones. In accordance with the frequency of selection, the midwives mentioned: vertical positioning, water immersion, massage, and counter-pressure. The nurses indicated: epidural analgesia, analgesics, and antispasmodics as well as massage and counter-pressure.

Similarly to the studies by Mieczkowska et al., the present study did not demonstrate statistically significant dependencies between the preferences referring to the mode of delivery and education, the place of residence, and the workplace [23].

\section{CONCLUSIONS}

The practiced profession influences women's decision regarding the mode of delivery. The midwives significantly more frequently declared a willingness to undergo vaginal delivery than the nurses. The level of labour anxiety declared by the nurses was statistically significantly higher than the anxiety level in the occupational group of midwives.

\section{Disclosure}

The authors declare no conflict of interest.

\section{References}

1. WHO recommendations: intrapartum care for a positive childbirth experience. World Health Organization, Geneva 2018 [online]: https://www.who.int/reproductivehealth/publications/intrapartum-care-guidelines/en/ (access: 3 July 2019).

2. WHO Statement on caesarean section rates. Reprod Health Matters 2015; 23: 149-150.

3. Boerma T, Ronsmans C, Melesse DY, et al. Global epidemiology of use of and disparities in caesarean sections. Lancet 2018; 392: 1341-1348.

4. Wielgoś M, Bomba-Opoń D, Bręborowicz GH, et al. Rekomendacje Polskiego Towarzystwa Ginekologów i Położników dotyczące cięcia cesarskiego. Ginekol Preinatol Prakt 2018; 3: 159-174.

5. Michałowska S, Zalewski M, Heimrath J, Zalewski J. Analiza sposobów ukończenia ciąży na podstawie preferencji ciężarnych oraz danych statystycznych z lat 2006-2010. Nowa Med 2012; 4: 67-75.
6. FIGO Committee for the Study of Ethical Aspects of Human Reproduction and Women's Health: Ethical issues in obstetrics and gynecology, 2012 [online]: https://www.figo.org/ figo-committee-and-working-group-publications (access: 4 July 2019).

7. Putyński L, Paciorek M. Kwestionariusz Lęku Porodowego (KLP II) Wersja Zrewidowana - konstrukcja i właściwości psychometryczne. Acta Universitatis Lodziensis. Folia Psychologica 2008; 12: 129-133.

8. Cavallaro FL, Cresswell JA, Ronsmans C. Obstetricians' opinions of the optimal caesarean rate: a global survey. PLoS One 2016; 11: e0152779.

9. Baran W, Skręt-Magierło J. Poglądy położnych na temat optymalnej drogi porodu. Pol Przegl Nauk Zdr 2016; 3: 209-215.

10. Bihler J, Tunn R, Reisenauer C, et al. The preferred mode of delivery of medical professionals and non-medical professional mothers-to-be and the impact of additional information on their decision: an online questionnaire cohort study. Arch Gynecol Obstet 2019; 299: 371-384.

11. Guzikowski W, Motak-Pochrzęst H, Kudaś D. Opinie kobiet rodzących na temat możliwości wyboru cięcia cesarskiego bez wskazań medycznych - na życzenie/żądanie. Gin Pol Med Project 2010; 3: 53-58.

12. Podwińska E, Janosz I, Bodzek P, et al. Opinie kobiet dotyczące możliwości wyboru cięcia cesarskiego na życzenie oraz roli anestezjologa podczas porodu. Gin Pol Med Project 2015; 3: 87-90.

13. Konopka J, Suchocki S, Puskarz R, Obst M. Cięcie cesarskie na życzenie pacjentki bez wskazań medycznych w opinii kobiet rodzących. Perinatol Neonatol Ginekol 2008; 1: 35-37.

14. Wardak K, Nagórska M, Łoziński T. Preferowana droga ukończenia ciąży wśród młodych kobiet. Przegląd Medyczny Uniwersytetu Rzeszowskiego i Narodowego Instytutu Leków w Warszawie 2011; 2: 239-248.

15. Bąk A, Biela-Mazur J, Dudzik K. Prośba o cesarskie cięcie czy należy łączyć ją z lękiem i depresją? Gin Pol Med Project 2016; 3: 59-65.

16. Ouyang YQ, Zhang Q. A study on personal mode of delivery among Chinese obstetrician-gynecologists, midwives and nurses. Arch Gynecol Obstet 2013; 287: 37-41.

17. Arikan DC, Özer A, Arikan I, et al. Turkish obstetricians' personal preference for mode of delivery and attitude toward cesarean delivery on maternal request. Arch Gynecol Obstet 2011; 284: 543-549.

18. Long Q, Kingdon C, Yang F, et al. Prevalence of and reasons for women's, family members', and health professionals' preferences for cesarean section in China: A mixed-methods systematic review. PLoS Med 2018; 15: e1002672.

19. Karlström A, Nystedt A, Johansson M, Hildingsson I. Behind the myth - few women prefer caesarean section in the absence of medical or obstetrical factors. Midwifery 2011; 27: 620-627.

20. Baran W, Skręt-Magierło J. Factors determining preferences of postpartum women regarding subsequent delivery mode. Hygeia Public Health 2016; 51: 275-280.

21. Błaszczak A, Pilch D, Szamlewska B. Badanie poziomu lęku kwestionariuszem STAI C.D. Spielbergera u kobiet w okresie okołoporodowym. Perinatol Neonatol Ginekol 2011; 4: 163-168.

22. Jones $L$, Othman $M$, Dowswell $T$, et al. Pain management for women in labour: an overview of systematic reviews. Cochrane Database Syst Rev 2012; 3: CD009234.

23. Mieczkowska K, Szymoniak K, Fryc D, Ćwiek D. Opinia pacjentek na temat cięcia cesarskiego na życzenie. Pielęg Pol 2017; 2: 240-245. 